\title{
Kesiapan Anggota KUD Dalam Menghadapi Replanting Kebun Kelapa Sawit Di Desa Kumain Kecamatan Tandun Kabupaten Rokan Hulu
}

\author{
Risman \\ Sekolah Tinggi Ilmu Ekonomi Riau (STIER) \\ Jln. HR. Subrantas 57 Panam Pekanbaru 28293 Telp. (0761) 63237 \\ E-mail : risman295@yahoo.co.id
}

\begin{abstract}
Cooperative became the economic base of the people, for the cooperatives is the same interests and worked together. Cooperative oil palm plantations became very concerned at the time of replanting the gardens, the original members of the cooperative have a relatively large income, but the time period replanting becomes very difficult. The survey conducted to 30 farmer groups who joined the KUD in the village of Rokan Hulu Kumain explained that the factor of readiness of farmers, among others, the lack of readiness of the farmers themselves $(4.503>2.056$ or $0.000<0.05)$. Compared with KUD readiness factors and also other parties such as the foster father and banking.
\end{abstract}

Keywords: Readiness Member, KUD

Sektor perkebunan di Propinsi Riau merupakan salah satu sektor yang mendapat prioritas utama, karena sektor ini diharapkan mampu menyerap tenaga kerja yang cukup banyak, mampu menyediakan kebutuhan berupa pangan, mampu menyumbang devisa serta memberikan kontribusi pada peningkatan Produk Domestik Propinsi Riau. Usaha perkebunan merupakan salah satu kegiatan ekonomi yang berperan dalam peningkatan pendapatan dan kesejahteraan petani, sesuai kultur alam propinsi Riau, pembukaan perkebunan kelapa sawit di propinsi riau cocok untuk dibudidayakan sebab kelapa sawit bisa diproses menjadi beberapa input ( bahan baku ) produk lain misalnya minyak goreng, bahan kosmetik, oli, biodisel dll.( Nurimansyah Hasibuan, Muslimin Nasution, $2000: 1$ )

Kecamatan Tandun adalah salah satu kecamatan yang berada di Kabupaten Rokan Hulu yang mempunyai lima desa sebagai daerah perkebunan kelapa sawit plasma ( pola kemitraan), dan diantaranya adalah desa Kumain yang masyarakatnya hidup sebagai petani kelapa sawit bahwa Kecamatan Tandun memiliki 4.652 Ha kebun kelapa sawit plasma, dimana desa Kumain memiliki areal terluas yakni $1.046 \mathrm{Ha}$ atau 22,48\%, dan untuk desa Tapung Jaya, Bono Tapung dan Dayo seluas 2.856 $\mathrm{Ha}$ atau 61,39\% sudah pada proses replanting, Desa Tandun 750 Ha masih dikategorikan tanaman produktif dan desa Kumain 1.046 baru pada tahap perencanaan tanaman akan di remajakan ( replanting ).

Replanting atau Penanaman kembali tanaman perkebunan yang sudah tidak produktif, adalah isu yang cukup hangat dikalangan petani perkebunan terutama petani perkebunan kelapa sawit. Pada tanamam kelapa sawit masa produktif adalah umur 5 sampai 25 tahun, dimana produksi rata- rata perhektar mencapai 2- 3 ton per bulan, namun jika umur tanaman sudah lebih dari 25 tahun maka produksi mulai menurun pada kisaran 1 sampai 1,5 ton perhektar / bulan.Pada kondisi ini pendapatan petani tidak lagi sanggup menopang biaya hidup sehari-hari, dan para petani dituntut untuk berfikir kreatif untuk mencari pendapatan lain diluar usaha kebun mereka.

Salah satu metode peremajaan tanaman yang memungkinkan petani masih menerima penghasilan selama masa peremajaan adalah dengan sistem underplanting, yaitu teknik peremajaan dengan menanam tanaman baru diantara tanaman tua. 
Dari segi pengusahaan, suatu kebun kelapa sawit dianggap sudah tua jika berumur sekitar 20 sampai 25 tahun dan perlu diremajakan. Peremajaan tanaman (replanting) dilakukan agar hasil produksi kebun sawit tidak menurun secara drastis. Pada tahap ini diperlukan perencanaan yang matang dan terperinci untuk menghindari terjadinya kerugian selama kegiatan peremajaan. Mengatasi hal tersebut, peremajaan dapat dilakukan secara bertahap dengan membagi areal tanaman tua menjadi beberapa wilayah pengerjaan.

Dalam underplanting perlu untuk membuat rencana dan desain kebun yang akan dikelola. Hingga ke masalah membersihkan tanaman atau bagian Tanaman terserang

Ganoderma, membuat pancang

jalur,pembuatan jalan dan saluran drainase inventarisasi pohon, menebang dan merencek (dicincang), membersihkan jalur tanam, membajak dan menggaru, membuat teras dan teknik konservasi, peracunan dengan mematikan tanaman tua yang belum di tumbangkan.

Satu hal lagi yang sangat penting adalah untuk membuka lahan pada areal peremajaan kebun sawit, hendaknya dilakukan dengan mengolah lahan tanpa membakar. Pekerjaan dan alat yang dipergunakan serta teknis pelaksanaan dalam pembukaan lahan pada areal kebun sawit ini tergantung pada kerapatan vegetasi dan cara yang digunakan. Ada dua cara membuka lahan pada areal peremajaan kebun sawit yaitu cara kombinasi antara manual-mekanis dan mekanis.

Kementerian Pertanian menerbitkan pedoman replanting sawit dan riset untuk pengembangan industri sawit. Pedoman peremajaan (replanting) perkebunan dan riset kelapa sawit ini menjadi dasar bagi Badan Pengelola Dana Perkebunan (BPDP) Sawit mengeluarkan dana bagi peremajaan kelapa sawit milik rakyat ( Tabloid Sinar Tani, Replanting Kelapa Sawit, 2016 ). Nantinya, pedoman replanting perkebunan dan riset kelapa sawit ini menjadi dasar bagi Badan
Pengelola Dana Perkebunan (BPDP) Sawit mengeluarkan dana bagi peremajaan kelapa sawit milik rakyat.

Kementan mengaku tengah melakukan finalisasi pedoman replanting dan riset untuk kebun kelapa sawit yang akan dijadikan acuan oleh BPDP itu. Dalam pedoman dari Kementan itu akan dijabarkan apa saja syarat untuk replanting. Dan bagaimana para petani sawit harus mengadakan akad kredit dengan perbankan untuk bisa di replanting perkebunan sawit mereka.

Adapun kesiapan anggota KUD atau petani dalam menghadapi replanting adalah kondisi dimana pada saat penanaman kembali para petani anggota KUD memiliki bekal atau penghasilan lain yang sanggup menopang seluruh biaya hidup, mulai dari kebutuhan makanan, pakaian dan tempat (kebutuhan pokok), biaya sekolah anak anak, biaya kesehatan, biaya biaya sosial seperti sumbangan pesta atau kado ulang tahun, biaya angsuran bank atau angsuran kendaraan bermotor dan masih banyak lagi biaya biaya tak terduga lainya.

Biaya biaya diatas harus dipersiapkan sedini mungkin, seperti dengan cara menanam tanaman sawit baru atau tanaman lain pada lahan yang lain, beternak, usaha perikanan, membuka bisnis perdagangan, jasa perbengkelan, dan usaha uaha lain yang mampu mengimbangi penghasilan kebun sawit yang mau direplanting, jika petani anggota KUD tidak mampu mempersiapkan ini maka para petani akan mengalami krisis ekonomi yang cukup berat karena proses peremajaan (replanting) membutuhkan waktu kurang lebih 5 tahun agar tanaman sawit mereka menghasilkan kembali. Biaya hidup manusia dari tahun ketahun seiring terjadinya inflasi, maka akan semakin meningkat, sementara pada saat replanting penghasilan dari kebun sawit mereka menjadi $0 \%$ atau tidak ada hasil sama sekali.

Menurut Yusnawati (2007:11), "kesiapan merupakan suatu kondisi dimana seseorang telah mencapai pada tahapan 
tertentu atau dikonotasikan dengan kematangan fisik, psikologis, spiritual dan skill". Menurut Suharsimi Arik unto (2001:54), "ke siapan adalah suatu kompetensi sehingga seseorang yang mempunyai kompetensi tersebut memiliki kesiapan yang cukup untuk berbuat sesuatu". Menurut Slameto (2010:13) "kesiapan adalah keseluruhan kondisi yang membuatnya siap untuk memberi respon atau jawaban di dalam cara tertentu terhadap suatu situasi. Penyesuaian kondisi pada suatu saat akan berpengaruh pada kecenderungan untuk memberi respon".

Dari beberapa teori itu dapat disimpulkan bahwa kesiapan adalah suatu kondisi yang dimiliki baik oleh perorangan maupun suatu badan dalam mempersiapkan diri baik secara mental, maupun fisik untuk mencapai tujuan yang dikehendaki. Suatu kondisi dikatakan siap setidak -tidaknya mencakup beberapa aspek, menurut Slameto (2010:14), ada tiga aspek yang mempengaruhi kesiapan yaitu:

1)Kondisi fisik, mental, dan emosional

2)Kebutuhan atau motif tujuan

3)Keterampilan, pengetahuan, dan pengertian yang lain yang telah dipelajari.

Slameto juga mengungkapkan tentang prinsip-prinsip readiness atau kesiapan yaitu:

1)semua aspek perkembangan berinteraksi (saling pengaruh mempengaruhi).

2)kematangan jasmani dan rohani adalah perlu untuk memperoleh manfaat dari pengalaman.

3)pengalaman-pengalaman mempunyai pengaruh yang positif terhadap kesiapan.

4)kesiapan dasar untuk kegiatan tertentu terbentuk dalam periode tertentu selama masa pembentukan dalam masa perkembangan (2010:15)

Konsep Kesiapan Anggota KUD Dalam Menghadapi Replanting

Adapun kesiapan anggota KUD dalam menghadapi replanting adalah kondisi dimana pada saat penanaman kembali para petani anggota KUD memiliki bekal atau penghasilan lain yang sanggup menopang seluruh biaya hidup, mulai dari kebutuhan makanan, pakaian dan tempat (kebutuhan pokok), biaya sekolah anak anak, biaya kesehatan, biaya biaya sosial seperti sumbangan pesta atau kado ulang tahun, biaya angsuran bank atau angsuran kendaraan bermotor dan masih banyak lagi biaya biaya tak terduga lainya.

Biaya biaya diatas harus dipersiapkan sedini mungkin, seperti dengan cara menanam tanaman sawit baru atau tanaman lain pada lahan yang lain, beternak, usaha perikanan, membuka bisnis perdagangan, jasa perbengkelan, dan usaha uaha lain yang mampu mengimbangi penghasilan kebun sawit yang mau direplanting, jika petani anggota KUD tidak mampu mempersiapkan ini maka para petani akan mengalami krisis ekonomi yang cukup berat karena proses peremajaan ( replanting ) membutuhkan waktu kurang lebih 5 tahun agar tanaman sawit mereka menghasilkan kembali. Biaya hidup manusia dari tahun ketahun seiring terjadinya inflasi, maka akan semakin meningkat, sementara pada saat replanting penghasilan dari kebun sawit mereka menjadi $0 \%$ atau tidak ada hasil sama sekali.

Faktor yang mempengaruhi kesiapan petani Meurut hasil penelitian Rita dkk (2014 : 15), menyebutkan bahwa terdapat faktor determinan kesiapan petani menghadapi masa replanting. Penelitian ini dilakukan dipropinsi Riau, yang menyebutkan faktor determinanya antara lain : Kondisi lahan yang dimiliki petani, Struktur organisasi (KUD), Kelompok Tani, dan masa tunggu.

Sedangkan dalam penelitian ini menambahkan dua variabel yang dianggap berkontribusi pada masa replanting yakni perbankkan dan pmerintah sebagai faktor pihak lain, dan membatasi pada faktor petani dan faktor KUD

\section{METODE}

Jenis penelitian adala penelitian survey, dengan populasi yang berjumlah 523 orang itu terbagi dalam 30 kelompok 
Tani yang masing masing kelompok telah mewakili seluruh anggota, maka dari 30 orang ketua kelompok tadi diambil sebagai sampel. Penelitian lapangan, dilakukan untuk mendapatkan data primer penelitian dengan menyebarkan melalui penyediaan angket berupa daftar pertanyaan maupun pernyataan yang diberikan kepada setiap responden yang telah ditetapkan terlebih dahulu untuk dijawab atau diisi. Untuk keterangan yang lebih mendalam tentang permasalahan yang diteliti, daftar pertanyaan yang dibuat tersebut dibuat sedetail mungkin, berisikan pertanyaan tentang fakta, pendapat dan informasi data dianalisis dengan metode kuantitatif.

\section{HASIL}

Koperasi merupakan badan usaha yang berdasarkan pada azas kekeluargaan, koperasi ini berdiri atas dasar kesamaan kepentingan pada setiap anggotanya. Anggota memiliki hak dan kewajiban yang sama terhadap koperasi. Koperasi di Indonesia sudah cukup berkembang dan sampai saat ini salah satu daerah yang terus mengembangkan koperasi adalah kecamatan Tandun. Koperasi Unit Desa ( KUD ) di Kecamatan Tandun berjumlah 5 unit KUD , merupakan unit usaha yang berkembang sudah semenjak lama dan sampai saat ini mempunyai anggota kurang lebih 2.326 orang.Adapun anggota KUD di Desa Kumain berjumlah krang lebih 523 orang, yang anggotanya sebagian besar berprofesi sebagai petani kelapa sawit yang umur tanamanya berkisar antara 25 - 30 tahun. Pada umur tersebut adalah umur yang dikategorikan pada umur tanaman yang tidak produktif.

\section{Kesiapan anggota}

Kesiapan petani sawit dalam menghadapi replanting dengan skor rata rata 3,25 yang artinya cukup siap. Dari empat indikator yang paling rendah kesiapanya adalah poin 2 sebesar 2,33 yang artinya kesiapanya rendah, diikuti dengan poin 1 sebesar 2,50 juga rendah. Sedangkan poin no 4 sebesar 4,33 yang artinya kesiapanya tinggi, disusul poin no 3 sebesar 3,83 yang artinya kesiapanya cukup tinggi. Rendahnya kesiapan ini disebabkan oleh sangat rendahnya pendapatan petani sawit dan cenderung semakin tingginya biaya hidup. Tingginya kesiapan pada no 4 karena pada masa replanting masing masing anggota KUD dituntut untuk mencari jalan keluar agar replanting ini tidak mengganggu perekonomian mereka.

\section{Faktor yang Mempengaruhi Kesiapan Petani}

\section{Faktor Diri Sendiri}

Kesiapan petani sawit dalam menghadapi replanting dengan skor rata rata 3,25 yang artinya cukup siap. Dari empat indikator yang paling rendah kesiapanya adalah poin 2 sebesar 2,33 yang artinya kesiapanya rendah, diikuti dengan poin 1 sebesar 2,50 juga rendah. Sedangkan poin no 4 sebesar 4,33 yang artinya kesiapanya tinggi, disusul poin no 3 sebesar 3,83 yang artinya kesiapanya cukup tinggi. Rendahnya kesiapan ini disebabkan oleh sangat rendahnya pendapatan petani sawit dan cenderung semakin tingginya biaya hidup. Tingginya kesiapan pada no 4 karena pada masa replanting masing masing anggota KUD dituntut untuk mencari jalan keluar agar replanting ini tidak mengganggu perekonomian mereka.

\section{Faktor KUD}

Faktor KUD dalam kesiapan petani sawit dalam menghadapi replanting. Dari hasil jawaban responden indikator yang mendapat skor tertinggi pada indikator pengurus KUD sudah dibenahi atau sudah dibentuk dan pada indikator partisipasi anggota dengan organisasi KUD dengan rata rata 2,83 yang artinya cukup siap. Dari empat indikator yang paling rendah kesiapanya adalah poin 2 sebesar 2,37 yang artinya kesiapanya rendah, diikuti dengan poin 3 sebesar 2,40 juga rendah. Rendahnya faktor KUD dalam kesiapan petani sawit dalam menghadapi replanting ini disebabkan oleh sangat rendahnya partisipasi KUD untuk melindungi anggota 
dalam menghadapi masa replanting serta kurangnya pemahaman dalam mengelola keuangan KUD dan tidak trasparannya laporan keuangan KUD dengan para anggota koperasi, sehingga pada saat akan dilaksanakan replanting para anggota koperasi merasa tidak siap.

\section{Faktor Pihak Lain}

Faktor pihak lain dalam kesiapan petani sawit dalam menghadapi replanting. Dari hasil jawaban responden indikator yang mendapat skor tertinggi terdapat pada indikator kebijakan mitra bapak angkat dalam proses replanting dengan rata rata 4,47 yang artinya setuju. Dari empat ndikator yang paling rendah kesiapanya adalah poin 3 sebesar 3,30 yang artinya responden menyatakan cukup setuju, diikuti dengan poin 4 sebesar 3,30 juga cukup setuju. Faktor pihak lain dalam mempengaruhi kesiapan anggota dalam kesiapan petani sawit dalam menghadapi replanting sangat tinggi, ini disebabkan karena anggota masyarakat sangat mengharapkan adanya campur tangan dari pihak lain untuk memperoses dan membantu anggota dalam menghadapi masa replanting, dimana dari jawaban responden mereka menyatakan dengan sistem bapak angkat sesuai dan memperoleh jawaban setuju dari anggota..

\section{Analisis Pengaruh Faktor yang Mempengaruhi Kesiapan Petani}

Untuk mengetahui pengaruh faktor diri sendiri, faktor KUD dan faktor pihak lain terhadap kesiapan anggotamenghadapi replanting tanaman perkebunan kelapa sawit di desa Kumain Kecamatan Tandundilakukan pengujian hipotesis dengan menggunakan beberapa analisis statistik. Bedasarkan hasil perhitungan dengan menggunakan bantuan SPSS, diperoleh data-data sebagai berikut:

\section{Tabel 1: Rekapitulasi Hasil Regresi Linear Berganda.}

\begin{tabular}{|l|l|}
\hline Variabel bebas & Koefisien regresi \\
\hline (Constant) & -0.852 \\
\hline Faktor Diri sendiri & 0.550 \\
\hline Faktor KUD & -0.029 \\
\hline Faktor Pihak lain & 0.465 \\
\hline
\end{tabular}

Jurnal Daya Saing
Pada penelitian ini yang menggunakan teknik analisis regresi linear berganda (Multiple Regression) dimaksudkan untuk mencari pengaruh antara variabel faktor diri sendiri, faktor KUD dan faktor pihak lain terhadap variabel terikat yaitu kesiapan anggotamenghadapi replanting tanaman perkebunan kelapa sawit di desa Kumain Kecamatan Tandun.

model persamaan regresi linear berganda sebagai berikut:

$\mathbf{Y}=\mathbf{a}+\mathbf{b}_{1} \mathbf{X}_{1}+\mathbf{b}_{2} \mathbf{X}_{2}+\mathbf{b}_{3} \mathbf{X}_{3}+\varepsilon$

Hasilnya adalah sebagai berikut:

$\mathrm{Y}=-0,852+0,550 \mathrm{X}_{1}+-0,029 \mathrm{X}_{2}+$ $0,465 \mathrm{X}_{3}+\varepsilon$

Dari persamaan regresi menunjukkan koefisien regresi dari $b_{1}, b_{2}, b_{3}$ bernilai positif dan negatif. Hal ini menunjukkan variabel-variabel bebas apabila ditingkatkan persamaannya akan menimbulkan peningkatan pula pada variabel terikatnya, seperti:

a. Konstanta sebesar -0,852, artinya jika faktor diri sendiri, faktor KUD dan faktor pihak lain (X) nilainya adalah 0, maka kesiapan anggota dalam menghadapi replanting tanaman perkebunan kelapa sawit di desa Kumain Kecamatan Tandun(Y) nilainya negatif yaitu sebesar 0,852 .

b. Nilai Koefisien faktor diri sendiri $(0,550)$ menunjukkan bahwa setiap perubahan kenaikan faktor diri sendiri sebesar 1 satuan, maka kesiapan anggota dalam menghadapi replanting tanaman perkebunan kelapa sawit di desa Kumain Kecamatan Tandunakan berubah naik sebesar 0.550 satuan dari perubahan faktor diri sendiri.

c. Nilai Koefisien faktor KUD (-0,029) menunjukkan bahwa setiap perubahan kenaikan faktor KUD sebesar 1 satuan, maka kesiapan anggota dalam menghadapi replanting tanaman perkebunan kelapa sawit di desa Kumain Kecamatan Tandunakan berubah 
menurun sebesar -0.029 satuan dari perubahan faktor KUD.

d. Nilai Koefisien faktor pihak lain $(0,465)$ menunjukkan bahwa setiap perubahan kenaikan faktor pihak lain sebesar 1 satuan, maka kesiapan anggotamenghadapi replanting tanaman perkebunan kelapa sawit di desa Kumain Kecamatan Tandun akan berubah meningkat sebesar 0.465 satuan dari perubahan faktor pihak lain.

Apabila nilai $\mathrm{R}$ mendekati +1 maka secara bersama-sama variabel-variabel bebas tersebut mempunyai hubungan positif yang cukup kuat. Berikut hasil dari pengolahan data dengan menggunakan bantuan SPSS yang dapat dilihat sebagai berikut :

Tabel 2: Hasil Output SPSS.

Model Summary

\begin{tabular}{|l|l|l|l|l|}
\hline Model & $\mathrm{R}$ & $\begin{array}{l}\mathrm{R} \\
\text { Square }\end{array}$ & $\begin{array}{l}\text { Adjusted } \\
\text { R Square }\end{array}$ & $\begin{array}{l}\text { Std. Error } \\
\text { of the } \\
\text { Estimate }\end{array}$ \\
\hline 1 & $.848^{\mathrm{a}}$ & .718 & .686 & 1.96919 \\
\hline
\end{tabular}

a. Predictors: (Constant), Faktor Pihak lain, Faktor Diri sendiri, Faktor KUD

\section{Sumber : Data Lampiran}

Dari Tabel 5.10 diperoleh nilai R. Square $\left(\mathrm{R}^{2}\right)$ sebesar $0.718(71,8 \%)$ ini menerangkan bahwa kesiapan anggota dalam menghadapi replanting tanaman perkebunan kelapa sawit di desa Kumain kecamatan Tandun dapat diterangkan oleh faktor diri sendiri, faktor KUD dan faktor pihak lain yaknisebesar $71,8 \%$. Sedangkan sisanya sebesar $28,2 \%$ menggambarkan variabel bebas lainnya yang tidak diamati dalam penelitian ini.

\section{Uji Secara Simultan (Uji F)}

Pembuktian hipotesis ini digunakan untuk melihat pengaruh variabel bebas secara mersama-sama terhadap variabel terikatnya. Dimana variabel bebasnya terdiri dari variabel faktor diri sendiri, faktor KUD dan faktor pohak lain, serta variabel terikatnya yaitu kesiapan anggotamenghadapi replanting tanaman perkebunan kelapa sawit di desa Kumain kecamatan Tandun. Dalam pengujian ini penulis merumuskan hipotesis statistik sebagai berikut:

Ho: Tidak ada pengaruh yang signifikan dari faktor diri sendiri, faktor KUD dan faktor pihak lainsecara bersama-sama terhadap kesiapan anggotamenghadapireplanting tanaman perkebunan kelapa sawit di desa Kumain kecamatan Tandun.

Hi: Ada pengaruh yang signifikan dari faktor diri sendiri, faktor KUD dan faktor pihak lain secara bersama-sama terhadap kesiapan anggotamenghadapireplanting tanaman perkebunan kelapa sawit di desa Kumain kecamatan Tandun.

Selanjutnya untuk pembuktian hipotesis penelitian apakah semua variabel bebas secara bersama-sama mempunyai pengaruh terhadap variabel terikatnya, maka dapat dilakukan dengan uji statistik F.

$$
\begin{aligned}
\mathrm{F}_{\text {Tabel }} & =(\mathrm{k}):(\mathrm{n}-\mathrm{k}-1) \\
& =(3):(30-3-1) \\
& =3: 26 \\
& =2.975
\end{aligned}
$$

Tabel 3: Koefisien Regresi Variabel Bebas Secara Simultan Terhadap Variabel Terikat.

ANOVA $^{b}$

\begin{tabular}{|l|l|l|l|l|l|}
\hline Model & $\begin{array}{l}\text { Sum of } \\
\text { Squares }\end{array}$ & Df & $\begin{array}{l}\text { Mean } \\
\text { Square }\end{array}$ & F & Sig. \\
\hline 1 Regression & 257.180 & 3 & 85.727 & 22.108 & $.000^{a}$ \\
Residual & 100.820 & 26 & 3.878 & & \\
Total & 358.000 & 29 & & & \\
\hline
\end{tabular}

a. Predictors: (Constant), Faktor Pihak lain,

Faktor Diri sendiri, Faktor KUD

b. Dependent Variable:

Kesiapan Anggota

Sumber : Data Lampiran

Hasil uji berpengaruh apabila $\mathrm{F}_{\text {-hitung }}>\mathrm{F}$ tabel. Dari hasil perhitungan menunjukkan bahwa $\mathrm{F}_{\text {-hitung }}$ adalah sebesar 22.108 (lihat lampiran) dan $\mathrm{F}_{\text {tabel }}$ dengan level signifikan sebesar $5 \%=2.975$ (lihat lampiran). Maka diperoleh $\mathrm{F}_{\text {-hitung }}$ lebih besar dari $\mathrm{F}_{\text {-Tabel }}$ $(22.108>2.975)$ atau sig $<0,05(0,00<$ $0,05)$.

Dengan demikian hipotesis yang mengatakan faktor diri sendiri, faktor KUD 
dan faktor pihak lainmerupakan faktor yang mempengaruhi kesiapan anggotamenghadapi replanting tanaman perkebunan kelapa sawit di desa Kumain kecamatan Tandunditerima.

Dari hasil perhitungan tersebut maka faktor diri sendiri, faktor KUD dan faktor pihak lain secara bersama-sama berpengaruh terhadap kesiapan anggota menghadapi replanting tanaman perkebunan kelapa sawit di desa Kumain kecamatan Tandun.

\section{Uji Secara Parsial (Uji t)}

Pembuktian Hipotesis dilakukan untuk melihat pengaruh antara variabel bebas terhadap variabel terikatnya, sehingga nantinya dapat diketahui apakah variabel bebas mempengaruhi variabel terikat, yakni kesiapan anggota menghadapi replanting tanaman perkebunan kelapa sawit di desa Kumain kecamatan Tandun dari dua variabel bebas yang diteliti.

Berdasarkan pada hasil perhitungan dengan menggunakan program SPSS versi 20, diperoleh besarnya nilai koefisien regresi secara parsial dengan variabel bebas yang diteliti. Yaitu seperti yang dilihat pada Tabel 5.12 berikut ini:

Tabel 4 Koefisien Regresi Variabel Bebas Secara Pasrial Terhadap Variabel Terikat.

Coefficients $^{\mathbf{a}}$

\begin{tabular}{|l|l|l|l|l|l|}
\hline \multirow{2}{*}{ Model } & \multicolumn{2}{|l|}{$\begin{array}{l}\text { Unstandardized } \\
\text { Coefficients }\end{array}$} & $\begin{array}{l}\text { Standardized } \\
\text { Coefficients }\end{array}$ & & \\
\cline { 2 - 5 } & $\mathrm{B}$ & Std. Error & Beta & $\mathrm{t}$ & Sig. \\
\hline 1 (Constant) & -.852 & 2.581 & & -.330 & .744 \\
$\begin{array}{l}\text { Faktor Diri } \\
\text { sendiri }\end{array}$ & .550 & .122 & .618 & 4.503 & .000 \\
$\begin{array}{l}\text { Faktor } \\
\text { KUD } \\
\text { Faktor } \\
\text { Pihak lain }\end{array}$ & -.029 & .315 & -.013 & -.092 & .927 \\
\hline
\end{tabular}

a. Dependent Variable: Kesiapan

Anggota

Dapat dibuktikan kebenaran hipotesis yang penulis ajukan secara partial dengan ketentuan :

a. Apabila $\mathrm{t}_{\text {-hitung }}>\mathrm{t}^{\mathrm{t}}$-Tabel bahwa variabel bebas dapat menerangkan bahwa benar terdapat pengaruh antara 2 variabel yang diteliti. b. Apabila t-hitung $<t_{\text {-Tabel }}$ bahwa variabel dapat menerangkan tidak terdapat pengaruh antara 2 variabel yang diteliti.

Uji $t$ ini dilakukan dengan membandingkan $\mathrm{t}_{\text {-hitung }}$ dengan $\mathrm{t}$-Tabel pada signifikan 5\% $(\alpha$ $=0,05$ )

$$
\begin{aligned}
\mathrm{t}_{\text {Tabel }}=\alpha / 2 & : \mathrm{n}-\mathrm{k}-1 \\
& =0,05 / 2: 30-3-1 \\
& =0,025: 26 \\
& =2,056
\end{aligned}
$$

Maka bedasarkan hasil pengujian pada variabel faktor diri sendiri $\left(X_{1}\right)$ dengan menggunakan bantuan SPSS diperoleh thitung sebesar 4,503 dengan sig. 0,000.Maka bila dibandingkan pada $\mathrm{t}$-tabel pada signifikan $\alpha=5 \%$, yakni sebesar 2,056 dapat dilihat bahwa t-hitunglebih besar dari ttabel atau sig. $<\alpha(0,05)(4,503>2.056$ atau $0,000<0,05)$. Dengan demikian dapat disimpulkan bahwa variabel $\mathrm{X}_{1}$ atau faktor odiri sendiri mempunyai pengaruh positif dan signifikan terhadap kesiapan anggota menghadapi replanting tanaman perkebunan kelapa sawit di desa Kumain kecamatan Tandun.

Bedasarkan hasil pengujian pada variabel faktor KUD $\left(\mathrm{X}_{2}\right)$ dengan menggunakan bantuan SPSS diperoleh thitung sebesar -0,092 dengan sig, 0,927. Maka bila dibandingkan pada $\mathrm{t}_{\text {-tabel }}$ pada signifikan $\alpha=5 \%$, yakni sebesar 2,056 dapat dilihat bahwa t-hitunglebih kecil dari ttabel atau sig. $>\alpha(0,05)(-0,092<2.056$ atau 0,927> 0,05). Dengan demikian dapat disimpulkan bahwa variabel $\mathrm{X}_{2}$ atau faktor KUD tidak mempunyai pengaruh terhadap kesiapan anggota menghadapi replanting tanaman perkebunan kelapa sawit di desa Kumain kecamatan Tandun.

Bedasarkan hasil pengujian pada variabel faktor pihak lain $\left(\mathrm{X}_{3}\right)$ dengan menggunakan bantuan SPSS diperoleh thitung sebesar 1,864dengan sig, 0,074. Maka bila dibandingkan pada $\mathrm{t}$-tabel pada signifikan $\alpha=5 \%$, yakni sebesar 2,056 dapat dilihat bahwa t-hitunglebih kecil dari ttabel atau sig. $>\alpha(0,05)(1,864<2.056$ atau 0,074> 0,05). Dengan demikian dapat 
disimpulkan bahwa variabel $\mathrm{X}_{3}$ atau faktor puhak lain tidak mempunyai pengaruh terhadap kesiapan anggota menghadapi replanting tanaman perkebunan kelapa sawit di desa Kumain kecamatan Tandun.

\section{PEMBAHASAN}

Bedasarkan hasil pengujian pada variabel faktor diri sendiri $\left(\mathrm{X}_{1}\right)$ dengan menggunakan bantuan SPSS diperoleh $\mathrm{t}_{\text {-hitung }}$ sebesar 4,503 dengan sig. 0,000. Maka bila dibandingkan pada $\mathrm{t}_{\text {tabel }}$ pada signifikan $\alpha=$ $5 \%$, yakni sebesar 2,056 dapat dilihat bahwa $\mathrm{t}_{\text {-hitung }}$ lebih besar dari t-tabel atau sig. $<\alpha$ $(0,05)(4,503>2.056$ atau $0,000<0,05)$. Dengan demikian dapat disimpulkan bahwa variabel $\mathrm{X}_{1}$ atau faktor odiri sendiri mempunyai pengaruh positif dan signifikan terhadap kesiapan anggota menghadapi replanting tanaman perkebunan kelapa sawit di desa Kumain kecamatan Tandun. hasil pengujian pada variabel faktor $\operatorname{KUD}\left(\mathrm{X}_{2}\right)$ dengan menggunakan bantuan SPSS diperoleh $\mathrm{t}$-hitung sebesar -0,092 dengan sig, 0,927 . Maka bila dibandingkan pada $\mathrm{t}_{\text {-tabel }}$ pada signifikan $\alpha=5 \%$, yakni sebesar 2,056 dapat dilihat bahwa t-hitunglebih kecil dari ttabel atau sig. $>\alpha(0,05)(-0,092<2.056$ atau $0,927>0,05)$.

Dengan demikian dapat disimpulkan bahwa variabel $\mathrm{X}_{2}$ atau faktor KUD tidak mempunyai pengaruh terhadap kesiapan anggota menghadapi replanting tanaman perkebunan kelapa sawit di desa Kumain kecamatan Tandun. Hal ini terjadi karena Kepengurusan KUD pada saat ini dalam keadaan transisi atau masa pergantian, bahkan sampai pada saat kami melakukan penelitian Pengurus KUD yang definitif belum terbentuk. Hasil pengujian pada variabel faktor pihak lain $\left(\mathrm{X}_{3}\right)$ dengan menggunakan bantuan SPSS diperoleh $\mathrm{t}_{\text {-hitung }}$ sebesar 1,864 dengan sig, 0,074. Maka bila dibandingkan pada $\mathrm{t}_{\text {tabel }}$ pada signifikan $\alpha=$ $5 \%$, yakni sebesar 2,056 dapat dilihat bahwa $\mathrm{t}_{\text {-hitung }}$ lebih kecil dari $\mathrm{t}_{\text {-tabel }}$ atau sig. $>\alpha(0,05)$ $(1,864<2.056$ atau $0,074>0,05)$. Dengan demikian dapat disimpulkan bahwa variabel $\mathrm{X}_{3}$ atau faktor pihak lain tidak mempunyai pengaruh terhadap kesiapan anggota menghadapi replanting tanaman perkebunan kelapa sawit di desa Kumain kecamatan Tandun. Hal ini disebabkan karena pihak lain akan mempunyai peranan jika ada fasilitator dalam hal ini adalah KUD, dan sementara organisasi KUD pada saat ini dalam keadaan pasif karena belum terbentuk kepengurusanya.

replanting merupakan bagian terpenting dalam suatu kegiatan budidaya sektor perkebunan, terutama untuk komoditas kelapa sawit. Apalagi kelapa Sawit merupakan salah satu komoditas perkebunan yang penting dalam perekonomian Indonesia, baik sebagai penghasil devisa maupun penyedia lapangan kerja, sumber pendapatan utama petani, sumber pendorong pertumbuhan wilayah dan sumber pelestari lingkungan. Indonesia merupakan produsen kelapa sawit utama terbesar dunia dengan luas areal mencapai 10 juta hektar dan produksi sebesar 33 juta ton CPO pada tahun 2015. Tanaman Sawit dikelola dalam tiga bentuk perkebunan, yaitu Perkebunan Rakyat (PR) seluas 40,15\%, Perkebunan BesarNegara (PBN) seluas 8,1 \%, dan Perkebunan Besar Swasta (PBS) seluas 51,75\%.

Dari tiga bentuk perkebunan tersebut, Perusahaan Besar Swasta (PBS) dan Perkebunan Rakyat (PR) merupakan yang terbesar dengan luas areal mencapai sekitar 91,90\% dari total areal kelapa sawit Indonesia. Salah satu masalah utama komoditas kelapa sawit Indonesia adalah rendahnya produktivitas tanaman, terutama untuk bentuk usaha perkebunan rakyat (PR). Produktivitas tanaman kelapa sawit saat ini pada Perkebunan Rakyat adalah 15 ton TBS/ha/tahun, sedangkan pada Perkebunan Besar sudah mencapai $>20$ ton TBS/ha/tahun.Tingkat produktivitas yang dicapai perkebunan kelapa sawit Indonesia ini masih berada di bawah potensi produktivitasnya mampumenghasilkan 25-30 ton TBS/ha/tahun.

Rendahnya produktivitas tanaman kelapa sawit Indonesia ini disebabkan oleh 
banyak faktor. Faktor utama adalah masih dominannya tanaman yang dikelola dengan penggunaan teknologi dan manajemen sederhana serta diusahakan dengan skala kecil, dominannya tanaman non-klonal dan tanaman tua dan tanaman yang sudah rusak.

Tanaman yang berasal dari bahan tanaman non-klonal potensi produksinya secara genetis memang rendah. Sedangkan tanaman yang sudah tua dan rusak, walaupun potensi produksinya secara genetis tinggi, secara keseluruhan akan menurunkan produktivitas tanaman pada blok yang sama.Karena itu, kegiatan replanting sudah menjadi kebutuhan yang harus segera direalisasikan agar produktivitas kelapa sawit di dalam negeri bisa ditingkatkan lagi.

Potensi pendanaan kegiatan replanting pun masih terbuka lebar. Misalnya dengan menggunakan program Kredit Usaha Rakyat (KUR) yang dapat dijangkau oleh petani kecil. (Agro Indonesia, menanti program replanting kelapa sawit, 13 juni 2016). Rendahnya produktivitas disebabkan lambannya peremajaan (replanting) tanaman sawit di perkebunan sawit milik petani yang berumur lebih 25 tahun. Petani membutuhkan bantuan dana pemerintah dan skema kemitraan dengan perusahaan sebagai avalis.

Menurut Freddy Wijaya, GM Asian Agri, menyebutkan Asian Agri sudah mempersiapkan petani binaannya untuk menghadapi kegiatan peremajaan tanaman. Pada tahun ini, diharapkan sekitar 1.150 petani binaan Asian Agri sudah bisa meremajakan lahan. Lalu bertambah menjadi 3.250 hektare pada 2016. Tahun berikutnya bertambah menjadi 3.550 ha. Dan pada 2018 naik menjadi 4000 ha. Menurutnya replanting ini dijalankan secara bertahap untuk menjamin suplai buah sawit ke pabrik. Sementara itu, lahan milik perusahaan ditargetkan dapat diremajakan sekitar 5.000 hektare per tahun.

Rustamari, petani binaan Asian Agri, mengatakan perusahaan sudah melakukan pembinaan kepada petani plasmanya semenjak tahun 2009. Pembinaan dilakukan dalam bentuk pelatihan mengenai peremajaan kelap sawit. Selain itu, dijalankan pula studi banding untuk melihat benih sawit Topaz yang akan digunakan sumber bahan tanaman mereka. Kendati demikian, dia meminta bantuan pemerintah berkaitan dengan pembiayaan replanting setelah dihapuskannya program revitalisasi perkebunan. Pasalnya, perbankan membebani pinjaman replanting petani dengan suku bunga komersil karena tidak ada lagi subsidi bunga dari pemerintah. "Petani memang punya dana cadangan tetapi tidak mencukupi untuk jaminan hidup selama masa replanting. Kebutuhan dana replanting sekitar 52 juta rupiah per hektare," kata Rustamari.

Menurut Herdrajat Natawijaya, Direktur Tanaman Tahunan, menyebutkan pihaknya sedang menyusun konsep replanting untuk diajukan kepada badan pengelola dana perkebunan sawit. Nantinya, duit hasil pungutan ekspor CPO bisa dipakai untuk membantu pembiayaan replanting petani. Sebelumnya, Bayu Krisnamurthi, Direktur Utama Badan Pengelola Dana Perkebunan Sawit, memprioritaskan peremajaan lahan petani sawit sekitar 300 ribu hektare.Konsep peremajaan akan dikoordinasikan dengan Direktorat Jenderal Perkebunan untuk mengidentifikasi lahan mana yang segera direplanting. (Sawit Indonesia, Peremajaan Sawit, Juni 2016)

Badan Pengelola Dana Perkebunan (BPDP) Sawit siap melakukan penanaman kembali (replanting) sekitar 2.000 ha tanaman kelapa sawit milik rakyat. Replanting ini merupakan program utama lembaga yang baru dibentuk ini. Direktur Utama BPDP Sawit Bayu Krisnamurthi mengatakan, kebun yang di-replanting tersebut merupakan hasil identifikasi selama lembaga ini terbentuk atau sekitar dua pekan lalu. "Dua minggu ini kami identifikasi 2.000 ha perkebunan rakyat yang siap di-replanting di Riau dan beberapa di Pekanbaru dan Jambi.

Salah satunya yang sudah sangat siap model revitalisasi perkebunan," ujarnya. Model replanting ini juga dalam 
rangka untuk mendukung program revitalisasi perkebunan yang dilakukan Kementerian Pertanian (Kementan). "Selama ini, proyek Kementan terhenti karena tidak diberikannya porsi dalam Anggaran Pendapatan dan Belanja Negara (APBN)," ujar Bayu. Soal replanting ini, kata Bayu, beberapa perusahaan swasta juga punya model sendiri untuk mendukung petani plasmanya dalam melakukan peremajaan tanaman sawit. Selain program replanting, program lainnya adalah program subsidi untuk biodiesel. "Kami sudah sepakat besarnya support untuk biodiesel. Perhitungannya sudah ada," jelasnya. Menurutnya, jika dihitung badan ini akan memberikan subsidi biodiesel Rp600-700 per liter.

Menurut Bayu, soal subsidi biodiesel ini bisa berubah tergantung dari harga CPO dan minyak fosil. "Ini on top dari Rp1.000 subsidi pemerintah terhadap solar yang ditetapkan dari APBN," katanya. Setelah kedua program tersebut terealisasi, lembaga ini baru akan fokus pada pembiayaan riset dan pengembangan SDM, promosi, dan advokasi. Direktur Peremajaan Perkebunan BPDP Sawit Witjaksana Darmosarkoro mengatakan dalam setahun ada sekitar 300.000 ha yang perlu di-replanting. Namun, upaya replanting ini terkendala oleh para petani yang kurang memahami pentingnya peremajaan tanaman ini. "Bahkan ketika mereka diminta untuk merealisasikan program ini, petani selalu meminta pengunduran jadwal replanting ," kata Witjaksana.

Witjaksana memahami pendapat petani tersebut mengingat hampir semua petani sawit menggantungkan hidupnya pada tanaman sawit. Oleh karena itu, kata dia, peran BPDP Sawit menjadi sangat penting untuk menyadarkan petani agar bersedia tanaman sawitnya diremajakan. Pada kesempatan itu, Witjaksana juga mengatakan bahwa dibutuhkan dana sekitar Rp60 juta per ha untuk dapat melakukan peremajaan. (Rabia Edra Almira, Ekonomi dan Bisnis, sindonews, Juni 2016, Jakarta). Direktorat Jenderal Perkebunan (2010) menyatakan, pengelolaan praktis yang dilakukan di perkebunan kelapa sawit umumnya bertujuan untuk mencapai keuntungan maksimal. Peremajaan merupakan upaya pengembangan perkebunan dengan melakukan peremajaan tanaman yang sudah tidak produktif dengan tanaman baru baik secara keseluruhan maupun bertahap. Peremajaan kelapa sawit juga terkait erat dengan upaya peningkatan produksi suatu kebun.

Dari segi pengusahaan, suatu kebun kelapa sawit dianggap sudah tua jika berumur sekitar 20 sampai 25 tahun dan perlu diremajakan. Peremajaan tanaman (replanting) dilakukan agar hasil produksi kebun sawit tidak menurun secara drastis. Pada tahap ini diperlukan perencanaan yang matang dan terperinci untuk menghindari terjadinya kerugian selama kegiatan peremajaan. Mengatasi hal tersebut, peremajaan dapat dilakukan secara bertahap dengan membagi areal tanaman tua menjadi beberapa wilayah pengerjaan. Tahapan peremajaan tanaman kelapa sawit meliputi kegiatan penumbangan tanaman lama, pencacahan cabang dan batang, perumpukan, penanaman tanaman penutup tanah (LCC), pemancangan, konservasi tanah, pembuatan lubang tanam, dan penanaman bibit tanaman kelapa sawit (Mangoensoekardjo dan Semangun 2005).

Program peremajaan setiap tahun sekitar 4\% dari total luas tanaman agar luas tanaman belum menghasilkan (TBM) tidak lebih dari $12 \%$ dari total seluruh areal tertanam. Hal ini dilakukan agar tandan buah segar (TBS) yang diolah pabrik kelapa sawit (PKS) tetap stabil. Peremajaan dilakukan sesuai dengan prosedur yang mengacu pada keselamatan dan kesehatan kerja (K3) karyawan serta mencegah dan menanggulangi terjadinya polusi terhadap lingkungan dengan penerapan konsep tanpa pembakaran (zero burning) ( Tim MCAR 2007).

\section{SIMPULAN}

Berdasarkan survey yang dilakukan kepada 30 orang ketua kelompok tani yang 
bergabung dalam KUD di desa Kumain Rokan Hulu menjelaskan bahwa faktor kesiapan dari petani antara lain kurangnya kesiapan dari diri sendiri para petani $(4,503>$ 2.056 atau $0,000<0,05)$. Dibandingkan dengan faktor kesiapan KUD dan juga pihak lain seperti bapak angkat dan perbankan.

\section{DAFTAR RUJUKAN}

Bayu Krisnamurthi, 2016, Sawit Indonesia, Tabloid Sinar Tani, Jakarta

Fadilla, 2011, Penumbangan Tanaman Kelapa Sawit, Media Perkebunan, Jakarta

Mangoensoehardjo, 2005, Replanting Kelapa sawit, Permentan, Jakarta

Muslimin Nasution, 2000, Perizinan Usaha Perkebunan, Dirjen Dephutbun, Jakarta

Qayuum Amri, 2016 , Menanti Replanting Kelapa Sawit, Agro Industri ,
Rabia Edra Elmira, 2016, Ekonomi dan Bisnis, SindoNews, Jakarta

Setya midjaja, 2006, Penanaman Kelapa Sawit, Kansius, Yogyakarta

Slameto, 2010 : 14, Aspek aspek Kesiapan, Jakarta

Sunarko, 2007, Penanaman Bibit Kelapa Sawit, Departemen Pertanian, Jakarta

Tim Bina Karya Tani, 2009, Pembibitan Kelapa Sawit, Bina Karya, Jakarta Yusnawati, 2007: 11, Teori Kesiapan dan Prilaku, Rineka , Jakarta 